\title{
Zona Positif Connected Envieroment Sebagai Pembelajaran Selama Social Distancing
}

\section{Positive Zone Connected Environment for Learning During Social Distancing \\ Sutrisno}

Universitas PGRI Semarang, Indonesia

Diterima: 30 Desember 2020; Disetujui: 07 Januari 2021; Diterbitkan: 31 Januari 2021.

\begin{abstract}
Abstrak
Penelitian ini bertujuan untuk mengetahui fenomena COVID - 19, yang menimbulkan perubahan situasi, sehungga menyimpulkan gagasan/teori umum yang luas. Penelitian ini merupakan research journal, desain penelitian menggunakan eksplanatori dengan pendekatan berpikir yang dilakukan secara induktif. Penelitian menghasilkan konsep kebaharuan Positif Connected Envieroment. Positif Connected Envieroment merupakan integrasi dari teori Social Distancing, Motivational Forces, dan teori Stres. Dimensi pembentuk konsep kebaharuan dijelaskan dalam pembahasan. Kesimpulan dari kajian ini menjelaskan bahwa pandemi COVID-19 berdampak pada dunia pendidikan, lingkungan yang berubah memaksa diterapkanya pembelajaran jarak jauh secara mendadak berpotensi menimbulkan stress pada dosen senior. Kewajiban dan tanggung jawab melaksanakan tridharma perguruan tinggi menjadikan dosen senior kreatif untuk mencari cara agar tetap terhubung dengan mahasiswa melakukan pembelajaran jarak jauh, namun dengan keterbatasan penguasaan applikasi. Penerapan konsep model Positif Connected Envieroment merupakan solusi bagi dosen yang mengalami keterbatasan penguasaan applikasi pembelajaran jarak jauh dengan memanfaatkan tatap muka terbatas, diskusi sederhana dan permainan teoritis aplikatif. Konsep model ini tercermin dalam perilaku proaktif antara dosen dan mahasiswa sehingga tercipta zona positif connected envieroment yang menyenangkan, tanpa paksaan dan mampu menghadirkan suasana baru proses pembelajaran.
\end{abstract}

Kata kunci; Pandemi COVID-19, Social Distancing, Motivational Forces, Teori Stres, Dosen

Abstract

This study aims to look at the COVID-19 phenomenon that causes changes in the situation, so that general ideas / theories can be concluded. This research is a research journal, the research design uses an explanatory thinking approach which is carried out inductively. This research resulted in the novelty concept of the Positive Connected Environment. Positive Connected Environment is an integration of Social Distancing theory, Motivational Forces, and Stress theory. The dimensions that make up the concept of novelty are being discussed. The conclusion of this study explains that the COVID-19 pandemic has an impact on the world of education, a changing environment where distance learning suddenly creates stress for the elderly. The obligation and responsibility to carry out tertiary tridharma training makes seniors creative to find ways to stay connected with students who are doing distance learning, but with limited mastery of applications. The application of the concept of the Positive Connected Environment model is a solution for lecturers who experience limited mastery of distance learning applications by utilizing face-to-face limitations, simple discussions and applied theory games. The concept of a behavior model in proactive behavior between lecturers and students so as to create a positive zone that is connected to a pleasant environment, without coercion and is able to present a new atmosphere in the learning process.

Keywords; The COVID-19 Pandemic, Social Distance, Motivation Power, Stress Theory, Lecturers

How to Cite: Sutrisno. (2021) Zona Positif Connected Envieroment Sebagai Pembelajaran Selama Social Distancing.PERSPEKTIF, 10(1):265-271

*Corresponding author: ISSN 2085-0328 (Print)

E-mail: sutrisnopgri12@gmail.com ISSN 2541-5913 (online) 


\section{PENDAHULUAN}

Indonesia merupakan negara dengan perubahan tercepat dalam mengelola program pendidikan, pergantian rezim maka program pendidikan berubah. Kurikulum 1947 atau Rentjana Pelajaran 1947 dengan konsep setiap pelajaran dihubungkan dengan kehidupan sehari-hari, Kurikulum 1952 atau Rentjana Pelajaran Terurai 1952 konsep program Pancawardhana, yaitu pengembangan kecerdasan, moral, keterampilan, emosional dan jasmani, Kurikulum 1964 atau Rentjana Pendidikan 1964 konsep membentuk manusia Pancasila sejati yang kuat, sehat jasmani dan rohani, peningkatan kecerdasan dan keterampilan, moral dan budi pekerti, dan yang terakhir adalah memiliki keyakinan beragama, Kurikulum 1968, 1975 dan Kurikulum 1984 menekankan pada model rencana pelajaran setiap satuan bahasan, Kurikulum 1984 disebut dengan Cara Belajar Siswa Aktif (CBSA), sedangkan Kurikulum 1994, 1999 dan Kurikulum 2004 penekananya pada Kompetensi, Kurikulum 2006 disebut dengan Tingkat Satuan Pendidikan, Kurikulum 2013 merupakan konsep yang lebih maju dengan memasukan pendidikan karakter secara eksplisit, menekankan tiga aspek penilaian, yaitu pengetahuan, keterampilan, dan sikap dan perilaku dan kurikulum selanjutnya merupakan penyempurnaan kurikulum 2013 hingga sekarang.

Kelemahan pergantian kurikulum tanpa disertai peningkatan sumber daya manusia dan infrastruktur yang memadai maka hasil tetap akan sama. Guncangan pendidikan terjadi pada akhir 2019 dan booming di awal 2020 dimana diterapkan nya status social distancing. Jarak sosial didefinisikan oleh pakar kesehatan merupakan cara bagaimana menghentikan dan memperlambat penyebaran penyakit (the Australian Government 2020). Apa yang ddilakukan selama jarak sosial oleh tenaga kesehatan bertujuan memperlambat penyebaran penyakit dengan menghentikan sumber penularan COVID-19 dan pencegahan penularan baru. Protokol pencegahan penularan COVID - 19 oleh Badan kesehatan dunia (WHO) untuk masyarakat umum tentang pengaturan kerja yang fleksibel seperti bekerja dari rumah, pembelajaran dari rumah, meminimalisir keramaian, menutup fasilitas dan layanan tidak penting, perlindungan terhadap kelompok yang rentan tertular, pembatasan pergerakan baik lokal, nasional dan internasional dan tetap dirumah, reorganisasi yang terkoordinasi dengan jaringan layanan kesehatan dan layanan sosial untuk terhubung dengan rumah sakit (Practice, 2020). Pembelajaran jarak jauh menjadi kendala sebuah universitas karena faktor sumber daya manusia dan infrastruktur yang belum memadai. Dosen senior tidak mengikuti perkembangan teknologi, mereka masih mempertahankan pola pembelajaran lama seperti mengajar tatap muka, menggunakan buku keluaran lama, absensi manual, melempar pertanyaan secara langsung (Prayitno, Sutrisno 2019), dan faktor dari modal capital yang dimiliki universitas belum memadai, perubahan dalam perguruan tinggi umumnya lambat terjadi, meskipun ada tekanan untuk melakukannya namun hambatan juga pada institusional terhadap inovasi dan perubahan menjelaskan beberapa alasan mengapa pendidikan tinggi bergerak lambat untuk memenuhi tantangan baru (Armstrong, 2019). Namun, tanggung jawab mahasiswa telah terpenuhi maka konsekwensinya mereka menuntut hak nya untuk memperoleh pembelajaran.

Proses pembelajaran jarak jauh (daring) memggunakan applikasi media sosial, google class, zoom meeting dan applikasi yang dibuat secara instan diterapkan. Lamanya proses social disntancing dari tanggal 5 Maret 2020 melebihi standar WHO empat belas hari berdampak pada lamanya proses pembelajaran jarak jauh tidak efektif dan menimbulkan permasalahan baru, stress, turunnya tingkat motivasi untuk belajar dan tidak efektif isolasi diri. Permasalahan baru institusi perguruan tinggi bagaimana mengatasi stres dosen dan mahasiswa sebab, stres dapat mempengaruhi kesehatan fisik, Perilaku, mental, dan sosial individu (Mills, Karagiannis, and Zulch, 2014). Bagaimana memotivasi dosen dan mahasiswa yang menurun sebab guncangan teknologi, perubahan budaya akademik secara mendadak mengakibatkan perubahan pada kualitas akademik, para dosen melakukan penelitian secara marathon untuk meningkatkan kembali motivasi mahasiswa untuk belajar dengan keterbatasan, sebab motivasi adalah salah satu faktor terpenting prestasi berkelanjutan mahasiswa (Karadağ, 2017). Akhirnya, bagaimana dosen untuk mengelola pembelajaran yang efektif dan apa yang harus 
dilakukan oleh institusi terhadap dosen dan mahasiswa selama isolasi berlangsung untuk mengurangi tingkat stres, hasil penelitian yang dilakukan oleh Brooks et al. (2020) menyatakan bahwa selama isolasi diri berdampak negatif terhadap psikologis, gejala stres, kebingungan, kemarahan, ketakutan infeksi, frustrasi, kebosanan yang disebabkan oleh informasi yang tidak memadai, kerugian finansial, dan stigma melekat.

Menciptakan lingkungan untuk menghindari stres dan membangkitkan kembali motivasi individu dosen dan mahasiswa selama status social distancing sangat dibutuhkan institusi perguruan tinggi sehingga proses akademik tetap berlangsung. Positif Connected Envieroment merupakan konsep model menciptakan lingkungan yang tetap terhubung antara dosen dan mahasiswa untuk kegiatan positif sehingga produktif pada masa social distancing diberlakukan. Penelitian dimulai dengan pendekatan kualitatif induktif, memerikasa teori - teori dari jurnal bereputasi internasional terkait dengan fenomena pandemi COVID-19 yang menjadi stresor sehingga motivasi menurun karena diberlakukanya status social distancing di masing -masing daerah termasuk di perguruang tinggi. Teori stres, teori motivasi dan social distancing dibahas secara detail pada bagian kajian literatur untuk mendapatkan gambaran yang jelas keterkaitan ketiga teori tersebut. Bagian pembahasan akan mengkaji secara komperhensif bagaimana konsep kebaharuan penciptaan pengetahuan Positif Connected Envieroment beserta dimensi, pada bagian pembahasan akan dijelaskan secara komperhensif hasil penelitian jurnal kualitatif dampak pembelajaran jarak jauh terhadap tingkat stres dosen menggunakan indikator Paul D. Bliese Jeffrey R. Edwards, pengukuran tingkat efektifitas kegiatan selama social distancing menggunakan indikator yang disarankan oleh badan kesehatan dunia dan yang terakhir bagaimana institusi memotivasi dosen dan mahasiswa secara fisik dan virtual dengan indikator vroom's.

\section{METODE PENELITIAN}

Penelitian ini merupakan research journal, yakni dengan meihat catatan sistematis, biasanya tertulis, yang disimpan oleh peneliti untuk tujuan mengamati dan merefleksikan fenomena yang relevan dengan studi penelitian tertentu. Metode ini paling banyak digunakan untuk mendokumentasikan peristiwa yang terjadi secara spontan atau yang terkait dengan pengalaman peneliti sehari-hari. Desain penelitian menggunakan eksplanatori. Penelitian Eksplanatori adalah penelitian bertujuan untuk menguji suatu teori atau hipotesis guna memperkuat atau bahkan menolak teori atau hipotesis hasil penelitian yang sudah ada sebelumnya. Penelitian eksplorasi dilakukan sebab dampak kejadian pembelajaran jarak jauh disebabkan oleh mewabahnya virus corona baru pertama kali terjadi dan penelitian yang berhubungan dengan dosen, mahasiswa dan institusi perguruan tinggi secara bersama - sama belum ada sebelumnya. Tujuannya adalah untuk mencari pola, hipotesis atau ide yang dapat diuji dan akan menjadi dasar untuk penelitian lebih lanjut (Neville, 2007), sementara penelitian terbaru Boru (2018), berpatokan hanya pada fenomena yang yang belum didefinisikan secara jelas. Pendekatan yang dilakukan secara induktif, penelitian induktif dimulai ketika fenomena COVID - 19, yang menimbulkan perubahan situasi, sehungga menyimpulkan gagasan/teori umum yang luas (Neville, 2007).

\section{HASIL DAN PEMBAHASAN}

Kejadian luar biasa di dunia pada akhir tahun 2019 dan awal 2020 di Indonesia berdampak buruk pada segala sendi kehidupan masyarakat, tidak terkecuali bagi dunia pendidikan. Lebih dari 1.014 .000 orang sembuh dari total 3,2 juta infeksi virus corona di dunia, Kasus di Indonesia melewati 10.100, dengan jumlah yang meninggal 792 orang dan angka sembuh 1.522 per tanggal 30 april 2020. Pemerintah terus berupaya mengambil langkah-langkah menekan sebaran virus corona Covid-19. Salah satunya dengan mengeluarkan kebijakan bagi masyarakat untuk bekerja di rumah. Untuk mengatasi penyebaran Covid-19 membuat kebijakan belajar dari rumah bagi pelajar dan mahasiswa, sebagian ASN bisa kerja dari rumah dengan online dan mengutamakan pelayanan prima dari masyakarat, Presiden Joko widodo, pada tanggal 15 Maret 2020 (www.liputan6.com). Keputusan pemerintah ditindaklanjuti dengan pemberlakukan status social distancing. Social distancing adalah campur tangan pemerintah dalam bidang sosial kemasyarakatan dengan 
tujuan untuk pencegahan dan pengendalian infeksi dengan cara mengurangi sentuhan fisik antara mereka yang terinfeksi dengan yang belum, sehingga dapat menghentikan atau memperlambat laju dan tingkat penularan penyakit di masyarakat (Martín-Calvo et al., 2020). Strategi social distancing diterapkan terhadap enam strategi yang berbeda: Penutupan sekolah, menjaga jarak mandiri dan teleworking, menjaga jarak dan teleworking plus penutupan sekolah, penutupan Restoran, kehidupan malam, dan penutupan budaya sosial, Penutupan tempat kerja yang tidak penting dan isolasi Total dengan penutupan sekolah dan tempat kerja yang tidak penting di dalam area metropolitan (Martín-Calvo et al., 2020). European Center for Disease Prevention and Control (2020) mendefinisikan social distancing adalah protokol tindakan yang dilakukan untuk meminimalisir kontak fidik dengan orang lain, tindakan untuk menghitung dampak sosial dilakukan untuk menekan penularan penyakit dan dengan demikian juga mengurangi tekanan pada layanan kesehatan. Dengan pengukuran social distancing terhadap individu dan kelompok. social distancing individu meliputi Isolasi kasus, Karantina kontak, Rekomendasi menginap di rumah. Sedangkan social distancing kelompok yaitu yang memengaruhi banyak orang seperti; Penutupan lembaga pendidikan, penutupan Tempat Kerja, Tindakan untuk populasi khusus, pembatalan pertemuan massal, wajib karantina dan menjaga jarak satu orang dengan orang lain dan perumahan satu dengan perumahan lain (European Center for Disease Prevention and Control, 2020).

Perguruan tinggi merupakan institusi yang tidak terbayangkan sebelumnya terkena dampak paling parah sebab, kejadian pembelajaran jarak jauh dipaksa untuk diterapkan. Berbagai kegagalan proses pembelajaran jarak jauh terjadi. Dosen senior yang memiliki tingkat keilmuan tinggi namun kurang memahami dalam penggunaan applikasi pembelajaran jarak jauh (Mpofu et al., 2012), penggunaan smartphone memakan waktu karena harus mulai dari awal untuk mempelajari penggunaanya (Killen, De K Marais, and Van Z Loedolff, 2004), dosen senior tdak terbiasa menggunakan smartphone dalam jangka waktu lama terkait dengan masalah penglihatan (Rung, Warnke, and Mattheos, 2014), tidak semua kampus menanggung kuota internet untuk pembelajaran jarak jauh (Prof and Tuncay, 2016), dari segi mahasiswa menemui kendala sebab tidak semua mahasiswa memiliki laptop, kuota internet yang terbatas dan tugas yang dibebankan dosen memiliki jangka waktu yang sama dalam penyelesaian (Hew and Cheung, 2014). Namun, pada tingkat isolasi mandiri maupun kolektif penelitian yang dilakukan oleh European Center for Disease Prevention and Control (2020)menyarankan bahwa pada saat isolasi diri efektifitas kegiatan harus berinteraksi dengan jaringan sosial diperkuat dan tetap terhubung.

Manfaat jejaring sosial lebih banyak dan bervariasi tergantung pada usia pengguna, budaya dan tujuan. Beberapa manfaat khas adalah sebagai berikut (Bandgar, Shikshan, and Mandal, 2015); bebas dalam Ekspresikan diri dalam hal pandangan, pendapat dan kepercayaan, berbagi informasi dalam hal audio, video, slide, foto dll.Membangun hubungan antara teman atau orang asing, membantu untuk mengatasi isolasi perasaan, mengembangkan kualitas kepemimpinan, keterampilan mengorganisir dan keterampilan teknis.Melatih diri mereka untuk belajar tentang perilaku sosial dan tentangnorma sosial dari budaya yang berbeda. Menunjukkan bakat dalam berbagai bentuk seperti fotografi, musik dll dan mengembangkan kemampuan untuk bekerja dalam tim. Mengeksplorasi informasi dan pengetahuan tentang perkembangan teknologi dan rasa ingin tahu.Melatih diri mereka untuk bekerja dengan sukses dalam masyarakat digital. Namun, jejaring sosial juga memiliki kelemahan (Eydman, 2019), yaitu; Memengaruhi fokus, konsentrasi, dan kegigihan. Mengurangi kesabaran dan pemikiran kritis. Membuang waktu. Menghindari komunikasi tatap muka. Menjadi kecanduan dan membuat perbandingan dengan orang lain.Meningkatkan ruang lingkup penipuan keuangan dengan mengungkapkan informasi personalia dan profesional. Mengungkapkan informasi rahasia dan Mudah menyebarkan virus, Trojan dan worm. Tuntutan sebagai dosen untuk tetap melakukan pengajaran ditengah pandemi virus corona menjadikan dosen senior menggunakan cara berbeda agar tetap terhubung dengan mahasiswanya.

Bagi banyak dosen senior kejadian pembelajaran jara jauh akibat pandemi virus 
corona pertama kali dalam sejarah dan pengalaman mereka, berkomunikasi dengan mahasiswa memberikan dukungan sosial yang penting. Ketika kejadian pandemi virus corona menyebar dan perguruan tinggi secara fisik ditutup, dosen dan siswa berhubungan melalui teknologi informasi untuk komunikasi tetap terbuka. Dosen menggunakan alat untuk terhubung dengan mahasiswa dan mempertimbangkan secara logis dengan biaya dan kemampuan (Smith et al., 2012). Selain itu, penggunaan alat komunikasi memainkan peran penting untuk memediasi kedekatan sosial dan emosional antara dosen dengan siswa, dan kemandirian dosen menentukan jadwal kuliah. Tetap terhubunnya dosen dengan mahasiswa memiliki motivasi yang tinggi untuk tetap menuntut ilmu, dosen dan mahasiswa memiliki kepuasan tersendiri (Valence), walaupun tidak bertemu secara tatap muka dan keterbatasan menggunakan aplikasi pembelajaran jarak jauh. Vroom (1964) menjelaskan bahwa Valence fokus pada orientasi emosional yang dipegang seseorang sehubungan dengan hasil (penghargaan). Kedalaman keinginan seorang karyawan akan imbalan [uang, promosi, waktu luang, manfaat] ekstrinsik atau [kepuasan] intrinsik. Manajemen harus menemukan apa yang dihargai. Valensi adalah kekuatan preferensi dosen untuk hadiah tertentu. Dengan demikian, peningkatan gaji, promosi, penerimaan terhadap teman satu profesi, penilaian oleh atasan, atau hadiah memiliki nilai lebih atau kurang berbeda bagi setiap dosen. Tidak seperti ekspektasi dan instrumentalitas, valensi dapat berupa positif atau negatif (Lunenburg, 2011). Jika seorang dosen memiliki preferensi yang kuat untuk mendapatkan hadiah, valensi positif dan sebaliknya valensi negatif. Prefernsi dosen tidak untuk mendapatkan hadiah namun adanya rasa tanggung jawab untuk menjalankan tri dharma perguruan tinggi secara moral di tengah lingkungan pandemi virus corona dan mengurangi tingkat stres disebabkan faktor lingkungan.

Kontribusi penelitian terhadap orang dan lingkungan diformalkan dalam teori stres orang-lingkungan (person-environment/ P-E) (Caplan, 1987). Premis utama teori P-E bahwa stres muncul bukan dari orang atau lingkungan secara terpisah, melainkan karena kesesuaian mereka satu sama lain (Edwards \& Caplan, 2014). Stres di tempat kerja (lingkungan) merupakan fenomena umum yang sedang meningkat karena faktor-faktor luar seperti kemajuan teknologi, perubahan ekonomi yang mungkin menyebabkan menjadi berlebihan (Nekzada and Tekeste, 2013). Stres dapat dianggap sebagai kondisi yang tak terhindarkan setidaknya pada satu titik waktu atau yang lain; namun juga dapat diminimalkan sejauh produktivitas dan kesehatan dosen dipertahankan yang dapat mengarah pada perguruan tinggi yang produktif. Stres jugaterikat pada perguruan tinggi di mana terjadi perubahan dalam pola pengajaran bersifat mendadak karena adanya pandemi virus corona dan dosen memiliki latar belakang budaya, umur, pengalaman, keahlian dankemampuan yang berbeda.

Singkatnya, menyebarnya COVID-19 menyebabkan diterapkanya status social distancing oleh pemerintah yang mewajibkan perguruan tinggi untuk melakukan proses perkuliahan dengan sistem pembelajaran jarak jauh namun sebagian besar dosen senior tidak mampu untuk mengikuti penggunaan aplikasi pembelajaran jarak jauh karena keterbatasan pengetahuan tentang teknologi sehingga menimbulkan stres. Rasa tanggung jawab yang tinggi untuk tetap menjalankan tri dharma perguruan tinggi menjadikan semangat dosen untuk menemukan solusi kreatif agar tetap terhubung dengan mahasiswa. Maka, Positif Connected Envieroment menjadi solusi dosen (terutama senior) tetap produktif ditengah pandemi COVID-19. Positif Connected Envieroment adalah menciptakan lingkungan yang positif agar tetap terhubung dosen dan mahasiswa melakukan pembelajaran jarak jauh dengan tatap muka terbatas, diskusi sederhana dan permainan teoritis aplikatif. Secara sederhana integrasi teori Positif Connected Envieroment digambarkan pada gambar 1 . 


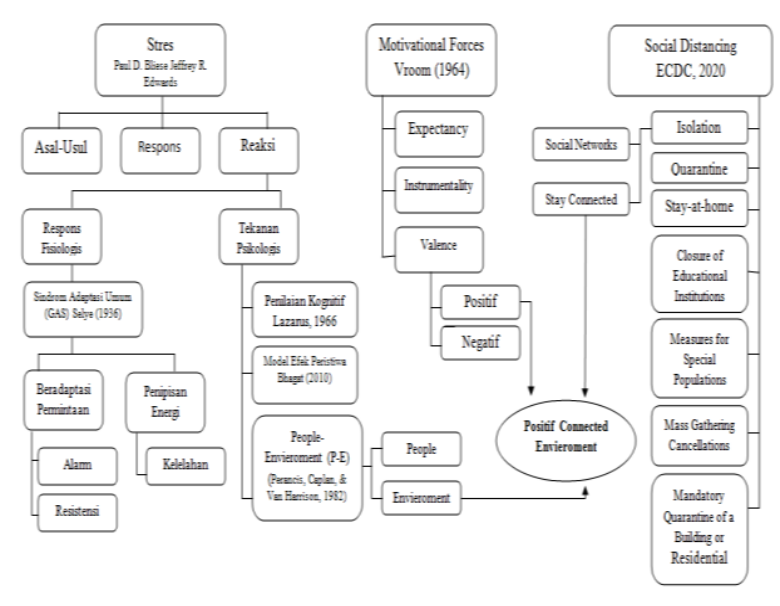

Gambar 1. Integrasi Teori Positif Connected Envieroment

Intergrasi teori (konsep kebaharuan) Positif Connected Envieroment terbentuk atas teori Social Distancing (European Center for Disease Prevention and Control, 2020), Motivational Forces(Vroom, 1964), dan teori Stres (Bliese et al., 2017). Tujuan dari penelitian ini adalah memberikan konsep model solusi untuk tetap menjalankan proses tri dharma perguruan tinggi khususnya bagi dosen senior yang mengalami keterbatasan pengetahuan pembelajaran jarak jauh menggunakan applikasi smartphone. Positif Connected Envieroment memiliki dimensi tatap muka terbatas, diskusi sederhana dan permainan teoritis aplikatif. Konsep model digambarkan pada gambar 2 .

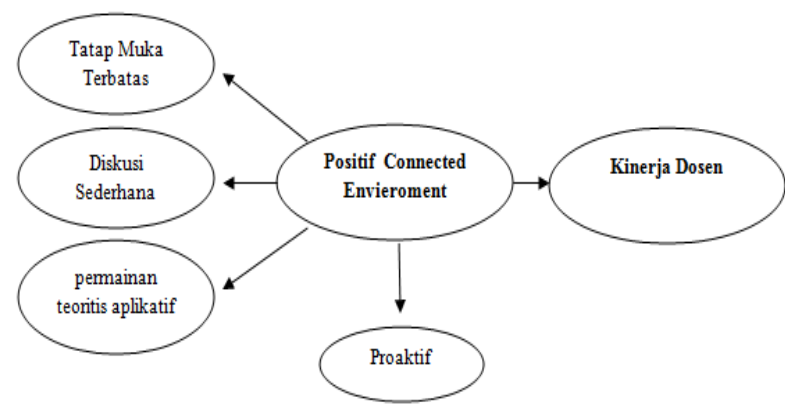

Gambar 2. Konsep Model Positif Connected Envieroment

Dalam situasi pandemi COVID-19 Kinerja dosen baik manakala seluruh tri dharma perguruan tinggi dilaksanakan, terutama pembelajaran jarak jauh. Pemeblajaran jarak jauh bagi dosen senior yang mengalami keterbatasan pengguasaan applikasi teknologi dapat menggunakan konsep model Positif
Connected Envieroment dengan memperhatikan dimensi tatap muka terbatas, diskusi sederhana dan permainan teoritis aplikatif. Positif Connected Envieroment tercermin dalam prilaku proaktif antara dosen dengan mahasiswa.

\section{SIMPULAN}

Pandemi COVID-19 berdampak pada dunia pendidikan, lingkungan yang berubah memaksa diterapkanya pembelajaran jarak jauh secara mendadak berpotensi menimbulkan stress pada dosen senior. Kewajiban dan tanggung jawab melaksanakan tridharma perguruan tinggi menjadikan dosen senior kreatif untuk mencari cara agar tetap terhubung dengan mahasiswa melakukan pembelajaran jarak jauh, namun dengan keterbatasan penguasaan applikasi. Penerapan konsep model Positif Connected Envieroment merupakan solusi bagi dosen yang mengalami keterbatasan penguasaan applikasi pembelajaran jarak jauh dengan memanfaatkan tatap muka terbatas, diskusi sederhana dan permainan teoritis aplikatif. Konsep model ini tercermin dalam perilaku proaktif antara dosen dan mahasiswa sehingga tercipta zona positif connected envieroment yang menyenangkan, tanpa paksaan dan mampu menghadirkan suasana baru proses pembelajaran.

Absensi masih menjadi kendala utama yang harus dipenuhi sebab kesulitan untuk menghadirkan mahasiswa dalam satu waktu secara bersama - sama mengalami kesulitan, jaringan internet kadang mengalami gangguan untuk melakukan diskusi sederhana dan permainan teoritis praktis. Penelitian selanjutnya diharapkan mampu mengungkapkan seberapa efektif bagi dosen melakukan tatap muka terbatas, bagaimana dosen mampu tetap produktif melakukan pembelajaran jarak jauh menggunakan konsep model Positif Connected Envieroment dan menciptakan zona positif connected envieroment.

\section{DAFTAR PUSTAKA}

Armstrong, Lloyd. (2019). "Barriers to Innovation and Change in Higher Education." TiaaCrefnstitute 11.

Bandgar, Bapurao, Jayawant Shikshan, and Prasarak Mandal. (2015). "ROLE OF SOCIAL NETWORK IN RECENT ERA ( 22-26).” (July). 
Boru, Tesfaye. (2018). “CHAPTER FIVE RESEARCH DESIGN AND METHODOLOGY 5. 1 . Introduction." (December): 41.

Brooks, Samantha K. et al. (2020). "The Psychological Impact of Quarantine and How to Reduce It: Rapid Review of the Evidence." The Lancet 395(10227):912-20.

Caplan, ROBERT D. (1987). "Person-Environment Fit Theory and Organizations: Commensurate Dimensions, Time Perspectives, and Mechanisms." Journal of Vocational Behavior 31(1):278-267.

European Center for Disease Prevention and Control. (2020). "Considerations Relating to Social Distancing Measures in Response to the COVID-19 Epidemic." (March):1-10.

Eydman, Michael. (2019). "Facebook SWOT Analysis RUNNING HEAD : BUS 5116 - UNIT 1 CASE STUDY , SWOT ANALYSIS BUS 5116 - Unit 1 Assignment Unit 1 Case Study - SWOT Analysis Michael Eydman University of the People." (October).

Hew, Khe Foon and Wing Sum Cheung. (2014). 'Students' and Instructors' Use of Massive Open Online Courses (MOOCs): Motivations and Challenges." Educational Research Review 12(June):45-58.

Jeffrey R. Edwards, Robert D. Caplan, R.Van Harrison. (2014). "Person-Environment Fit Theory." Encyclopedia of Quality of Life and Well-Being Research 4776-78.

Kanfer, Ruth and Gilad Chen. (2016). "Motivation in Organizational Behavior: History, Advances and Prospects." Organizational Behavior and Human Decision Processes 136(December):619. $\mathrm{R}$

Karadağ, Engin. (2017). "The Factors Effecting Student Achievement: Meta-Analysis of Empirical Studies." The Factors Effecting Student Achievement: Meta-Analysis of Empirical Studies (May 2017):1-337.

Killen, R., A. De K Marais, and P. Van Z Loedolff. (2004). "Success and Failure in Distance Education: Perceptions of South African Students and Lecturers in Business Management." South African Journal of Higher Education 17(2).

Lunenburg, Fred C. (2011). "Expectancy Theory of Motivation: Motivating by Altering Expectations." International Journal of Business Administration 15(1):1-6.

Martín-Calvo, David, Alberto Aleta, Alex Pentland, Yamir Moreno, and Esteban Moro. (2020). "Effectiveness of Social Distancing Strategies for Protecting a Community from a Pandemic with a Data-Driven Contact Network Based on Census and Real-World Mobility Data." Https://Covid-19-Sds.Github.Io/1-9.

Mills, Daniel, Christos Karagiannis, and Helen Zulch.
2014. "Stress - Its Effects on Health and Behaviour: A Guide for Practitioners Stress Health Behavior Arousal Emotions Stress Audit." Vet Clin Small Animal 44(2014):52541.

Mpofu, Vongai et al. 2012. "Challenges of Virtual and Open Distance Science Teacher Education in Zimbabwe." International Review of Research in Open and Distance Learning 13(1):207-19.

Nekzada, Najmoddin and Selamawit Fisseha Tekeste. 2013. "Stress Causes and Its Management at the Work Place." P.hd Thesis 0-66.

Neville, Colin. 2007. "Effective Learning Service: Introduction to Research and Research Methods." Bradford University School of Management 1-44.

Practice, BMJ Best. (2020). "Coronavirus Disease 2019." World Health Organization 2019(April):2633.

Prayitno, Sutrisno, Mahben Jalil. (2019). “THE EFFECT OF DISRUPTING CHANGES ON SENIOR LECTURERS." Jurnal Organisasi Dan Manajemen 15(1):1-16. Prof, Assist and Nazime Tuncay. 2016. "Smartphones as Tools for Education." Journal of Educational and Instructional Studies in the the World (May):20-31.

Rung, Andrea, Frauke Warnke, and Nikos Mattheos. (2014). "Investigating the Use of Smartphones for Learning Purposes by Australian Dental Students." JMIR mHealth and uHealth 2(2):e20.

Smith, Madeline E., Duyen T. Nguyen, Charles Lai, Gilly Leshed, and Eric P. S. Baumer. (2012). "Going to College and Staying Connected: Communication between College Freshmen and Their Parents." Proceedings of the ACM Conference on Computer Supported Cooperative Work, CSCW 789-98. 